\title{
Analysis of the current state and development of direct carbon fuel cells with an alkaline electrolyte
}

ABSTRACT: Among the numerous modern, high-efficiency energy technologies allowing for the conversion of chemical energy of coal into electricity and heat, the Direct Carbon Fuel Cells (DCFC) deserve special attention. These are devices that allow, as the only one among all types of fuel cells, to directly convert the chemical energy contained in solid fuel (coal) into electricity. In addition, they are characterized by high efficiency and low emission of pollutants. The paper reviews and discusses previous research and development works, both around the world and in Poland, into the technology of direct carbon fuel cells with an alkaline (hydroxide) electrolyte.

KEYWORDS: direct carbon fuel cell, alkaline electrolyte, high efficiency energy technologies, fossil carbons, biochar

\section{Introduction}

Electrical energy is currently a condition for the development of the economic and civilizational world. The dynamics of electrical energy consumption in individual countries or regions of the world depends primarily on the number of inhabitants, the level of economic, social and

\footnotetext{
${ }^{1}$ Częstochowa University of Technology, Faculty of Infrastructure and Environment, Department of Energy Engineering, Częstochowa; e-mail: akacprzak@is.pcz.pl
} 
civilization development as well as on the structure and efficiency of energy use. For example, the report of the International Energy Agency (Report... 2017) shows that in order to meet the growing demand for electrical energy, by 2040, China needs to add the equivalent of today's US energy system to its power infrastructure, while India needs the equivalent of the European Union's energy system. In turn, the report of the BP group (Report... 2016a) shows that by 2035 there should not run out of energy despite the fact that the demand will grow by $34 \%$ at an average rate of $1.4 \%$ per year. According to BP analysts, fossil fuels will remain the dominant energy source in this period. It is forecast that they will satisfy $60 \%$ of the anticipated increase in demand and will constitute almost $80 \%$ of global energy supplies, despite the rapid growth in the importance of other energy sources. In our country, the strategic issue is the use of hard coal and brown coal, which form the basis of the Polish energy system. In 2015, coal provided over 50\% of primary energy supplies, the second largest share among the countries of the Organization for Economic Cooperation and Development (OECD) and $81 \%$ of total electrical energy generation (Report... 2016b).

Generation of electrical energy in a conventional manner, mainly as a result of combustion of fossil fuels, exerts a negative impact on the natural environment. During the conversion of chemical energy of coal in power plants and combined heat and power plants, unwanted gas products $\left(\mathrm{CO}_{2}, \mathrm{CO}\right.$, nitrogen oxides, sulfur oxides, heavy metals, etc.) and solid (fly ash, slag) are formed, which when introduced into the environment cause air pollution, surface water pollution, and soil degradation.

The increase in energy demand and the problem of environmental pollution force us to look for new low-emission and highly-efficient energy sources, among which fuel cells should be paid special attention.

Direct carbon fuel cells are modern, alternative sources of electrical energy in which direct conversion of chemical energy of fuel into electrical energy takes place without the need to implement a long chain of changes which must be implemented in the thermodynamic cycle of a typical thermal power plants. When energy is supplied to the fuel cell in the form of chemical energy of fuel, it is immediately converted into electrical energy. The operation of fuel cells, if continuity of fuel and oxidant supply is ensured, may theoretically last endlessly, whilst their construction and operating principle is the same as in all galvanic cells. They consist of two electrodes (an anode and cathode), separated by a type II conductor, on which electrochemical oxidation reactions (anode) and reduction (cathode) take place. The connection of the electrodes with the electric circuit causes the current to flow. In contrast to the circuits of thermal engines, chemical energy in direct carbon fuel cells is directly converted into electrical energy, bypassing the heat generation stage. The efficiency of the cell does not depend on the temperature difference in the device and is not limited by the maximum efficiency of the Carnot cycle, which is why it often exceeds $50 \%$, which in addition to the simplicity of this system surpasses even the most modern conventional coal burning fossil power plants. These devices also generate less pollution in comparison with traditional sources of electrical energy, because the product of electrochemical reactions is water or a pure $\mathrm{CO}_{2}$ stream (depending on the type of cell and the fuel used). 
Fuel cells may be powered with different types of fuels: gas $\left(\mathrm{H}_{2}, \mathrm{CO}, \mathrm{CH}_{4}\right)$, liquid (methanol) and solid fuel (coal), thanks to which they may be considered as universal generators of electrical energy. In the case of hydrogen fuel cells, the problem is the production of fuel, there are also difficulties associated with its storage and transport, which is expensive and dangerous. This problem does not affect direct carbon fuel cells that can be directly supplied with "carbon". The fuel for this type of cell may be almost any substance containing the carbon element, including fossil carbons.

This paper reviews and analyzes the current research and development works, both in the world and in Poland, into the technology of direct carbon fuel cells with alkaline (hydroxide) electrolyte.

\section{Direct carbon fuel cells}

A direct carbon fuel cell is an electrochemical device which directly converts chemical energy of elemental carbon into electrical energy. The substrates supplied to this type of fuel cell are the carbon element (contained, among others, in hard coals, brown coal, carbonized biomass, graphite, soot, coke, etc.) and oxygen (pure or contained in atmospheric air), while the products are: electrical energy, pure stream of carbon dioxide, and mineral residue. The coal fuel is introduced into the anode space of the cell and in the electrochemical reaction, carried out at elevated temperature, oxidizes to $\mathrm{CO}_{2}$, generating electric current (Fig. 1).

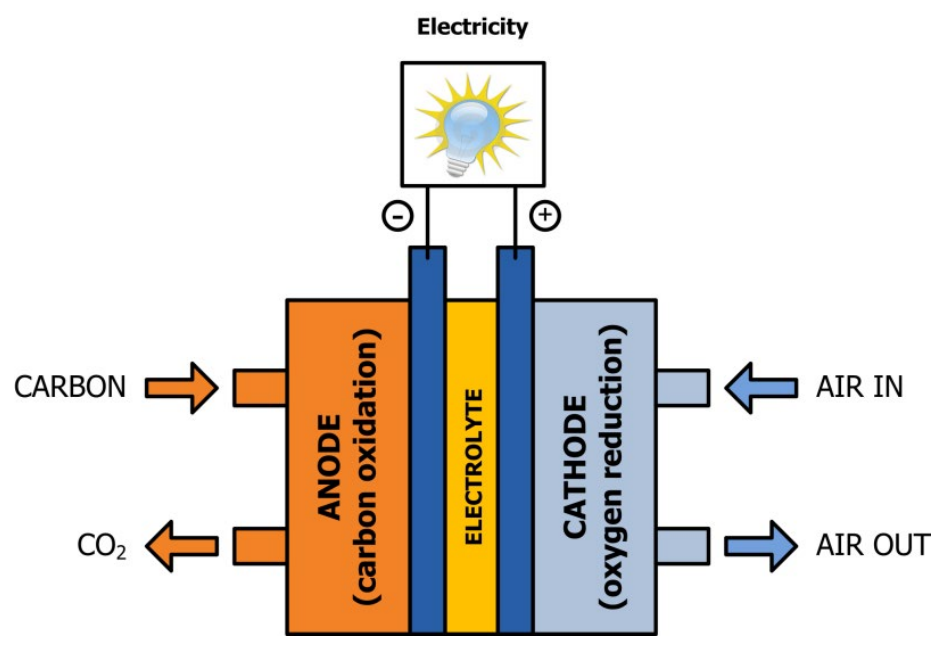

Fig. 1. The basic scheme of construction and operating principle of a direct carbon fuel cell

Rys. 1. Ogólny schemat budowy i funkcjonowania węglowego ogniwa paliwowego 
Currently used around the world are the DCFC-type cells which differ one another primarily by the type of electrolyte used. The type of electrolyte determines both the configuration of the device itself and the temperature of its operation. There are used four basic types of electrolytes: molten carbonates, oxygen-stable ceramic materials (most often zirconium oxide $\mathrm{ZrO}_{2}$ stabilized with yttrium oxide $\mathrm{Y}_{2} \mathrm{O}_{3}$ ), aqueous solutions of hydroxides and molten hydroxides. Recently, cells using mixed electrolytes (so-called hybrid) have also been developed.

As a result of the use of different types of electrolytes in DCFC, different electrochemical processes occur in the electrodes. The effect of these processes is the potential difference between the electrodes and the product of the carbon dioxide stream generated in the general reaction (1). By connecting the electrodes with an external circuit, the cell becomes a source of electrical energy.

$$
\mathrm{C}+\mathrm{O}_{2}=\mathrm{CO}_{2}
$$

The voltage under electrostatic conditions (electromotive force - SEM or otherwise the cell's reversible potential - E) is an important parameter characterizing direct carbon fuel cells. The reversible potential of the cell for the general reaction (1) running in the DCFC at $700 \mathrm{~K}$ is obtained by dividing the Gibbs free energy change $\left(\Delta \mathrm{G}_{700 \mathrm{~K}}=-395,37 \mathrm{~kJ} \mathrm{~mol}^{-1}\right)$ by the product of the Faraday constant $\left(\mathrm{F}=96485,3 \mathrm{C} \mathrm{mol}^{-1}\right)$ and the number of electrons transferred in a single redox reaction $(n=4)$. The value of this potential calculated from equation (2) is $1.025 \mathrm{~V}$.

$$
\mathrm{E}=-\Delta \mathrm{G} / \mathrm{nF}=1,025 \mathrm{~V}
$$

Importantly, the reversible potential of cells directly fed with coal practically does not change with the cell's operating temperature. In addition, direct carbon fuel cells enjoy a number of other advantages among which one should mention: the use of solid fuel - elementary coal, which can be obtained from many different sources (including fossil carbons), high theoretical (100\%) and real (50-80\%) efficiency.) (Kacprzak et al. 2016; Basu ed. 2007), low emission of pollutants $\left(\mathrm{SO}_{2}, \mathrm{NOx}\right.$, dusts) and about $50 \%$ reduction of $\mathrm{CO}_{2}$ emissions per unit of generated electrical energy (compared to a conventional thermal power plant).Due to high efficiency, the DCFC are able to help to reduce the rate of depletion of fossil fuels, since there is needed more fuel to produce the same amount of energy in a power plant than in fuel cells. In addition, the DCFC may form an element of distributed cogeneration systems producing electrical energy and heat from a few $\mathrm{kWe}$ to several dozen/several hundred $\mathrm{kWe}$. Thanks to the above-mentioned advantages, the coal-powered cells may becomethe key technology in the future for "clean" production of electrical energy and heat, especially in distributed energy systems. 


\section{Direct carbon fuel cells with an alkaline electrolyte}

In direct carbon fuel cells with an alkaline electrolyte, water solutions of hydroxides or molten hydroxides are used as electrolyte. In individual electrodes of such cells there take place the following reactions:

$\downarrow$ anode

$$
\mathrm{C}+4 \mathrm{OH}^{-} \rightarrow \mathrm{CO}_{2}+2 \mathrm{H}_{2} \mathrm{O}+4 \mathrm{e}^{-}
$$

cathode

$$
\begin{gathered}
\mathrm{O}_{2}+2 \mathrm{e}^{-} \rightarrow \mathrm{O}_{2}{ }^{2-} \\
\mathrm{O}_{2}{ }^{2-}+2 \mathrm{H}_{2} \mathrm{O}+2 \mathrm{e}^{-} \rightarrow 4 \mathrm{OH}^{-}
\end{gathered}
$$

These types of cells enjoy a number of advantages, among which first mentioned should be (Zecevic et al. 2005): high ionic conductivity, high activity of electrochemical oxidation of coal, which allows to obtain a high degree of its use, and a relatively low operating temperature, which in turn allows to apply cheaper construction materials and avoid the formation of undesirable $\mathrm{CO}$ as a result of the Boudouard reaction.

The disadvantage of direct carbon fuel cells with an alkaline electrolyte is the risk of carbonate formation in the reaction of the $\mathrm{CO}_{2}$ formed on the anode with the electrolyte. This unfavourable phenomenon causes electrolyte degradation. Carbonate formation may be limited by increasing the amount of water in the electrolyte, e.g. by supplying humidified air to the cell or by modifying the structure of the device itself (Zecevic et al. 2005).

The first DCFC with alkaline electrolyte with power of $1.5 \mathrm{~kW}$ and consisting of 100 individual cells (the target) forming the stack (Fig. 2a) was developed in 1896 by the American engineer William W. Jacques (Jacques 1986). Each cell (Fig. 2b) was made of a steel crucible (cathode) and a carbon rod (anode) containing a small amount of ash. A single fuel cell was characterized by a voltage of about $1 \mathrm{~V}$ and a current density of $100 \mathrm{~mA} \mathrm{~cm}^{-2}$. The Jacques cell was working at temperatures ranging from $673-773 \mathrm{~K}$ using molten sodium hydroxide as the electrolyte.

The main research and development centres currently involved in the development of direct carbon fuel cell with an alkaline electrolyte technologies are:

$\checkmark$ University of Hawaii, Hawaii Natural Energy Institute - HNEI, USA,

$\checkmark$ Scientific Applications \& Research Associates, SARA, USA,

$\downarrow$ University of West Virginia, USA,

$\checkmark$ Brown University, USA,

$\checkmark$ Czestochowa University of Technology, Department of Energy Engineering, Poland. 
a)

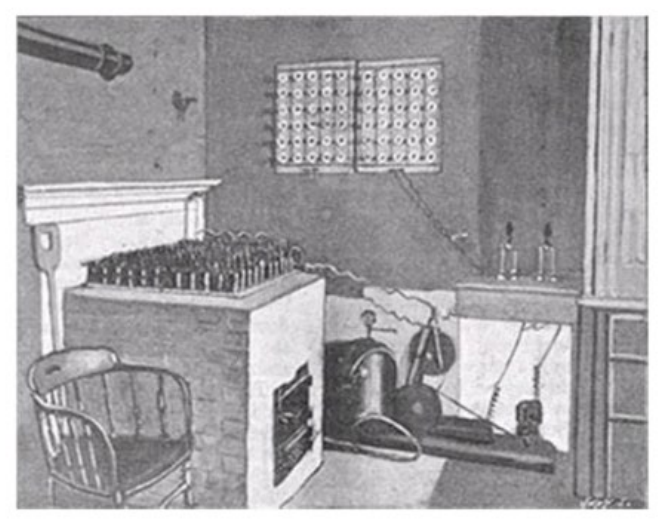

b)

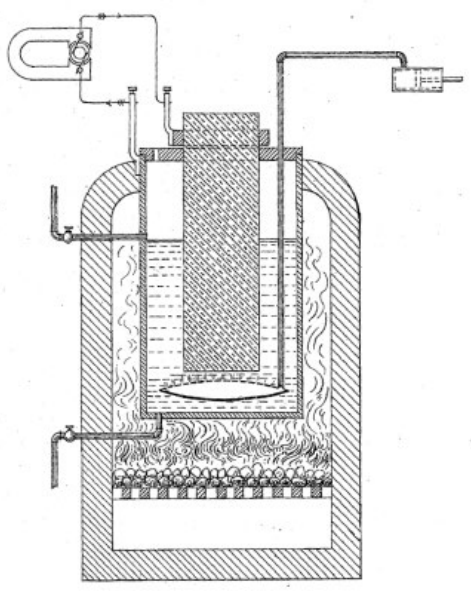

Fig. 2. Drawings of William W. Jacques' carbon fuel cell; a) fuel cell stack, b) a single fuel cell Source: figures redrawn based on reference Jacques 1986

Rys. 2. Szkice konstrukcji ogniwa węglowego Williama W. Jacques'a: a) stos ogniw, b) pojedyncza cela ogniwa

\subsection{Aqueous solutions of hydroxides}

Early research on direct carbon fuel cells with electrolyte in the form of aqueous hydroxide solutions was carried out in autoclaves at $473 \mathrm{~K}$ and $3 \mathrm{MPa}$ pressure (Lowry 1945). The autoclave container was an anode, while an iron rod was used as the cathode. The fuel was raw brown coal dispersed in the electrolyte. As a result of the experiments, a voltage of about $0.55 \mathrm{~V}$ was obtained from the cell in noncurrent conditions, which, however, quickly dropped to zero.

Later on, the research on this type of cell was started at the Hawaii Natural Energy Institute - HNEI (University of Hawaii, USA) (Nunoura et al. 2007; Antal and Nihous 2008). The diagram of the structure of the tested cell is shown in Figure 3. In the presented model, aqueous solutions of potassium, sodium, lithium, cesium, and magnesium hydroxides were used as the electrolyte. The cell was working at a pressure of $3.5 \mathrm{MPa}$ and a temperature in the range of $353-518 \mathrm{~K}$ using compacted biochar as fuel.

During the tests, there were examined various types of materials and various cathode construction solutions (Fig. 4), of which solutions (a) and (f) proved to be the best.

The highest values of the basic electrical parameters were achieved for the electrolyte in the form of a mixture of aqueous solution of potassium and lithium hydroxide $(6 \mathrm{M} \mathrm{KOH} / 1$ $\mathrm{M} \mathrm{LiOH}$ ) obtaining voltage under electrified conditions equal to $0.574 \mathrm{~V}$ and maximum current and power densities of $43.6 \mathrm{~mA} \mathrm{~cm}^{-2}$ and $6.5 \mathrm{~mW} \mathrm{~cm}^{-2}$ respectively at $518 \mathrm{~K}$ and pressure of $3.58 \mathrm{MPa}$ (Nunoura et al. 2007). According to the authors, the electrodes should work at different temperatures: a cathode below $500 \mathrm{~K}$, and an anode above $510 \mathrm{~K}$. The two-temperature cell 


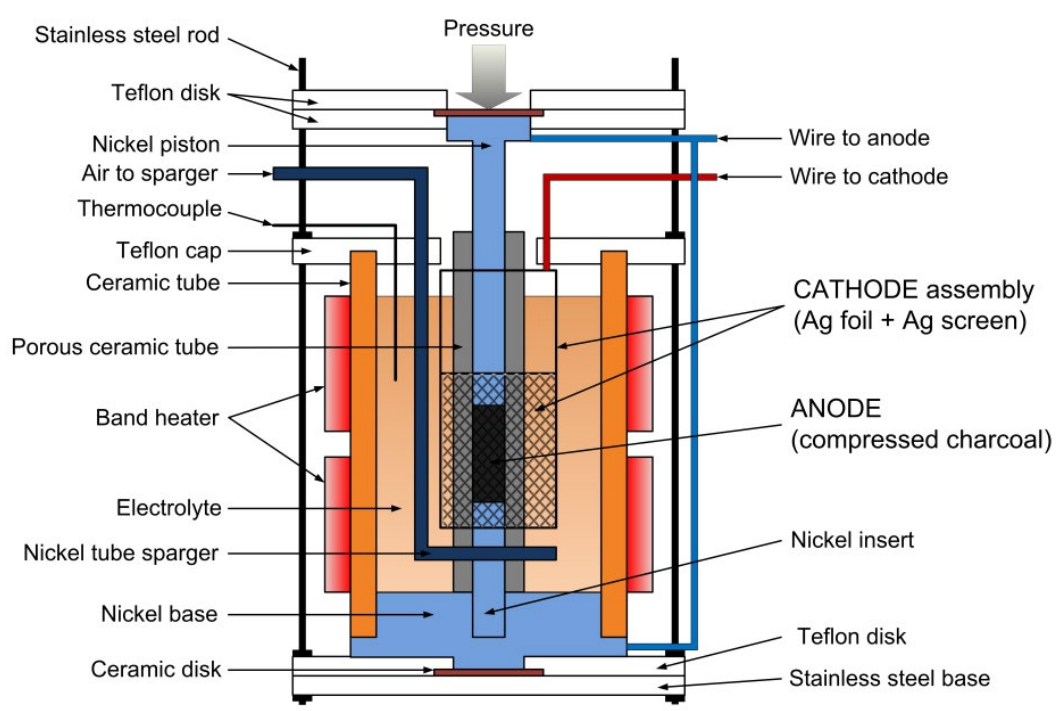

Fig. 3. Schematic drawing of an aqueous hydroxide electrolyte direct carbon fuel cell tested in HNEI Source: figure redrawn based on reference Wolk et al. 2007

Rys. 3. Schemat ogniwa węglowego z elektrolitem w postaci wodnego roztworu wodorotlenków badanego w HNEI

(a)

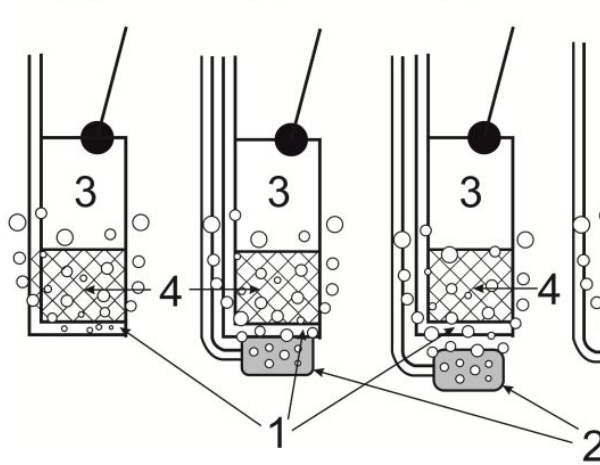

(d)

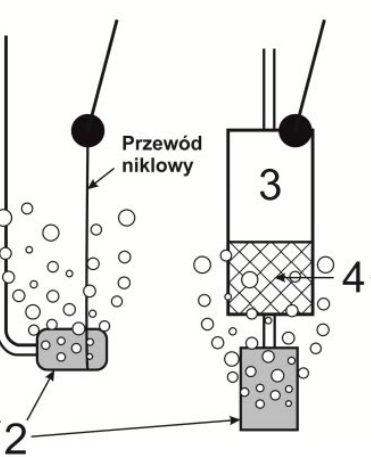

(f)

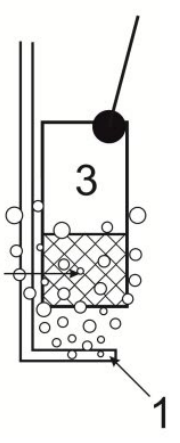

Fig. 4. Variation of cathode configurations used in carbon fuel cell constructed in HNEI; 1 - nickel perforated tube sparger, 2 - high nickel alloy porous sparger, 3 - silver foil, 4 - silver screen mesh Source: figures redrawn based on reference Nunoura et al. 2007

Rys. 4. Rozwiązania konstrukcyjne katody stosowane w ogniwie paliwowym skonstruowanym przez HNEI: 1 - układ rozprowadzania powietrza wykonany z niklowej perforowanej rurki, 2 - porowaty areator wykonany ze stopu wysokoniklowego, 3 - srebrna folia, 4 - srebrna siateczka

structure is designed to eliminate some of the problems encountered during the research, including evaporation of water from the cathode area. The authors have already developed the design of the new link, and its construction is being planned. In addition, the challenges facing the 
HNEI team are primarily the improvement of the voltage and current parameters obtained from the cell, the development of a continuous fuel supply method, and the assessment of scalability.

\subsection{Molten hydroxides}

\subsubsection{Scientific applications \& research associates (SARA)}

On the basis of the design and principle of operation of the Jacques fuel cell, the American company Scientific Applications \& Research Associates (SARA) has designed and patented its own cell of this type. During many years' worth of research, the research team has developed two structural solutions for the cell:

A. With one electrolyte chamber,

B. With two electrolyte chambers.

In the first solution (Fig. 5a), a cylindrical graphite rod serving at the same time as a fuel and current collector of the anode was immersed in molten sodium hydroxide located in a cylindrical or cuboidal container, which also was a cathode current collector. The humidified air was supplied to the bottom of the container with electrolyte and distributed over its walls by means of a special perforated system made of low carbon steel. The cell construction was simple and used inexpensive construction materials, e.g. titanium doped carbon steel (Zecevic et al. 2003, 2005).

a)

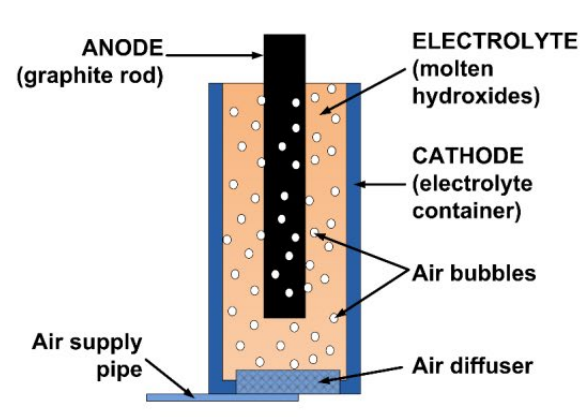

b)

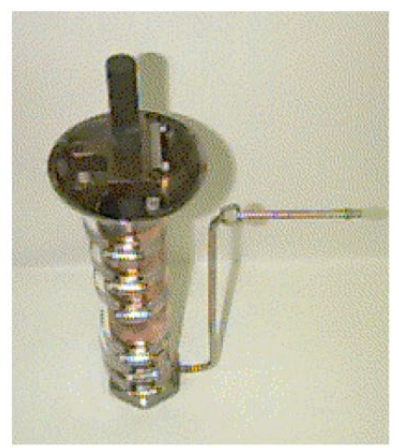

c)

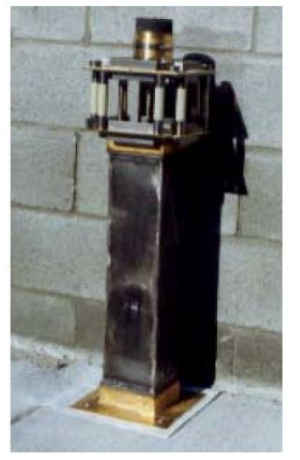

Fig. 5. Schematic of SARA's direct carbon fuel cell design with one electrolyte chamber; a) fuel cell scheme, b) view of the prototype with an anode surface of $26 \mathrm{~cm}^{2}$ and c) $300 \mathrm{~cm}^{2}$

Source: figures redrawn based on reference Zecevic 2003

Rys. 5. Konstrukcje ogniwa węglowego firmy SARA z jedną komorą elektrolitową: a) schemat ogniwa, b) widok prototypu o powierzchni anody wynoszącej $26 \mathrm{~cm}^{2}$ i c) $300 \mathrm{~cm}^{2}$ 
During the research works conducted with a fuel cell with one chamber, there were manufactured several prototypes. The Mark II-D prototype (Fig. 5b) had an anode surface equal to $26 \mathrm{~cm}^{2}$ (the distance between the electrodes was $1.3 \mathrm{~cm}$ ) and allowed to obtain a current of 7-8 A $\left(\approx 270 \mathrm{~mA} \mathrm{~cm}^{-2}\right)$ and a maximum power density of $57 \mathrm{~mA} \mathrm{~cm}^{-2}$. The cell prototype marked as Mark III-A (Fig. 5c) had an anode of $300 \mathrm{~cm}^{2}$ (the distance between the electrodes was $3 \mathrm{~cm}$ ) and the current intensity exceeding $40 \mathrm{~A}\left(\approx 150 \mathrm{~mA} \mathrm{~cm}^{-2}\right)$. The Mark III-A model enabled obtaining an average power of $12-20 \mathrm{~W}$ during $540 \mathrm{~h}$ of operation (instantaneous power surges were even 35-50 W). This model generated maximum current and power densities of $150 \mathrm{~mA} \mathrm{~cm}^{-2}$ and $40 \mathrm{~mW} \mathrm{~cm}{ }^{-2}$, respectively. The efficiency of the non-optimized Mark III-A cell operating at $50 \mathrm{~mA} \mathrm{~cm}^{-2}$ has been estimated at around $60 \%$. However, the calculations indicate that in the case of a power plant with a tested cell, there may be achieved the efficiency of 70-75\% (Patton 2003). In addition, it was found that the work of the tested cell depends on the cathode material used, the intensity of aeration, the operating temperature, and the size of the device itself.

In the second construction solution (Fig. 6), a special porous separator made of perforated nickel foil wrapped around a steel pipe constituting the supporting structure was placed between the anode and cathode. The aim of this solution was to eliminate the problem of electrolyte degradation caused by carbonates produced during the cell's operation. The developed cell construction causes that the electrolyte composition in the proximity of the anode and cathode is different and therefore they do not mix. The porous separator separating the electrode spaces may ultimately also be made of ceramic materials or corrosion-resistant porous metals, where the thickness thereof should be small enough to limit the ion flow resistance and ensure minimal mechanical strength (Patton 2003; Zecevic et al. 2003).

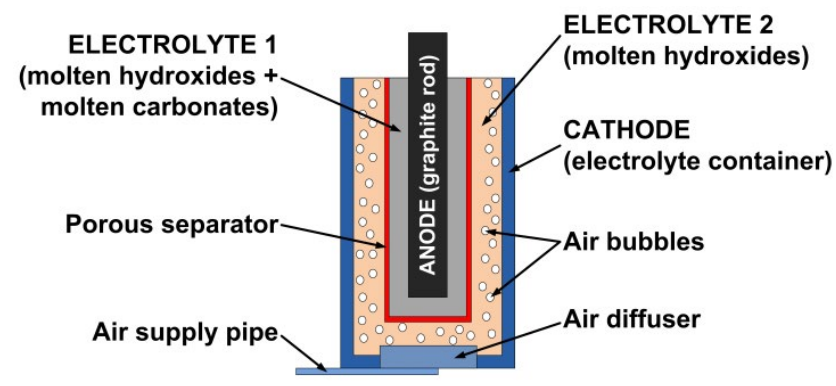

Fig. 6. Schematic of SARA's direct carbon fuel cell design with two electrolyte chambers Source: figures redrawn based on reference Patton 2005

Rys. 6. Konstrukcja ogniwa węglowego firmy SARA z dwiema komorami elektrodowymi: a) schemat ogniwa, b) widok poglądowy

Tests using a prototype with two electrode chambers included a test with a separator made of porous zirconium oxide. The cell was working for 120 hours without degradation of the voltage and current parameters. Analysis of the electrolyte composition in the cathode space carried outfollowing the test showed the absence of carbonates, which initially proved the correctness 
of the adopted concept (Patton 2005). The intended future application of the developed cell is in distributed generation installations, also as part of hybrid systems which additionally use wind turbines or photovoltaic cells.

\subsubsection{University of West Virginia}

After 2004, the SARA research team began cooperation with the University of West Virginia (USA) (Patton 2005) within the scope of development of methods for manufacturing solid cylindrical carbon rods which were fuel for the tested cell. The solid carbon electrodes were produced from various amounts of petroleum coke, coal packs as a binder and one or two carbonaceous fuels. Hackett and his collaborators from the University of West Virginia (Hackett 2007) also carried out numerous test in order to determine the cell characteristics (the developed prototype shown in Fig. 7 structurally and functionally similar to the SARA cell shown in Fig. 5) depending on the properties of the developed fuel. The cell was working at temperatures in the range of 873-973 K with electrolyte in the form of molten $\mathrm{NaOH}$. During the tests, both graphite rods and carbon electrodes were used to power the cells. Using graphite, there was obtained a current density of $230 \mathrm{~mA} \mathrm{~cm}^{-2}$, while the maximum voltage of unloaded cell was $0.788 \mathrm{~V}$. Carbon electrodes made it possible to achieve a higher voltage $(1.044 \mathrm{~V})$, however, the obtained current densities were up to only $35 \mathrm{~mA} \mathrm{~cm}{ }^{-2}$. Power densities generated in a graphite rod powered cell did not exceed $84 \mathrm{~mW} \mathrm{~cm}^{-2}$, while in the case of coal, values no higher than $33 \mathrm{~mW} \mathrm{~cm}^{-2}$ were observed. Differences in the obtained electrical parameters, according to the authors, were associated with a higher resistance of carbon electrodes in comparison with graphite electrodes.

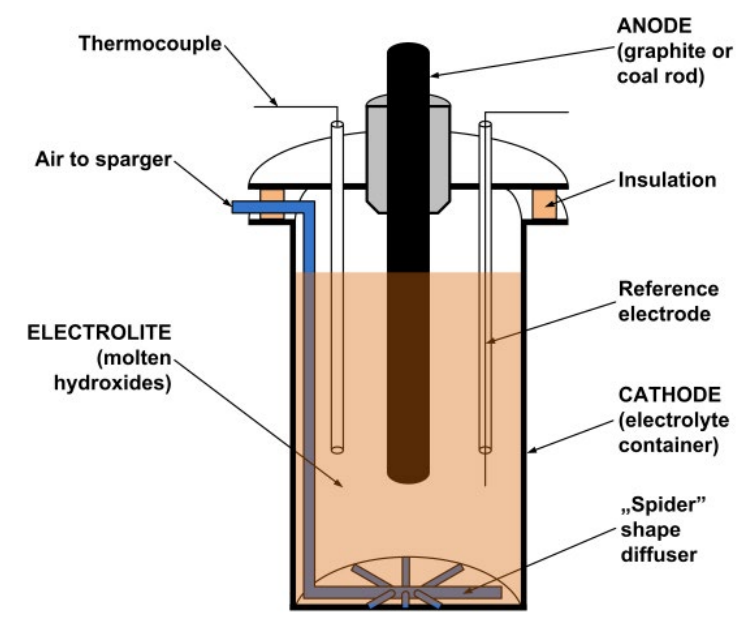

Fig. 7. Schematic drawing of West Virginia University direct carbon fuel cell Source: figure redrawn based on reference Hackett 2007

Rys. 7. Schemat węglowego ogniwa paliwowego skonstruowanego na Uniwersytecie West Virginia 
The cell using carbon rods, unlike a cell powered by graphite rods, was also characterized by unstable performance. During some tests, the carbon rods began to crack and break. According to the researchers, this was due to the use of coal packs as binder, which turned out to be more reactive than the actual fuel.

\subsubsection{Brown University}

Recently, studies on carbon cells with electrolyte in the form of molten hydroxides were also started at the University of Brown (USA) (Guo et al. 2013, 2014). Experiments were conducted for several design variants of the cell. The anode was made in two configurations: A1) nickel net with a mesh size of $149 \mu \mathrm{m}$ fastened in a frame made of chromium-nickel wire, A2) nickel-sized rectangular shaped container $(25 \mathrm{~mm} \times 25 \mathrm{~mm} \times 5 \mathrm{~mm})$ with holes drilled in one of the side walls that have been covered with nickel mesh. The cathode was also made in two different construction variants: K1) nickel tube with a diameter of $6.35 \mathrm{~mm}$ placed inside a larger tube with a diameter of $12.7 \mathrm{~mm}$. Outside the smaller tube a nickel mesh was created which was the surface where the oxygen reduction reaction took place, whereas the cathode K2) was built similarly to the A2 anode, the difference being that inside there was an air distribution system allowing to obtain fine gas bubbles.

The diagram of cell structure with anode A1 and cathode $\mathrm{K} 1$ is shown in Fig. 8. The electrolyte used during the tests was molten sodium hydroxide or eutectic mixture of $\mathrm{NaOH}-\mathrm{KOH}$ (54-36 mol\%). As the fuel, there was used C-3014 activated carbon. The determined characteristics of cells with two different electrolytes at $773 \mathrm{~K}$ indicated that the voltage of the unloaded cell working with $\mathrm{NaOH}$ electrolyte was higher than in the case of electrolyte as a mixture of $\mathrm{NaOH}-\mathrm{KOH}$, on the other hand, the maximum values of current density were higher for the second tested electrolyte composition.

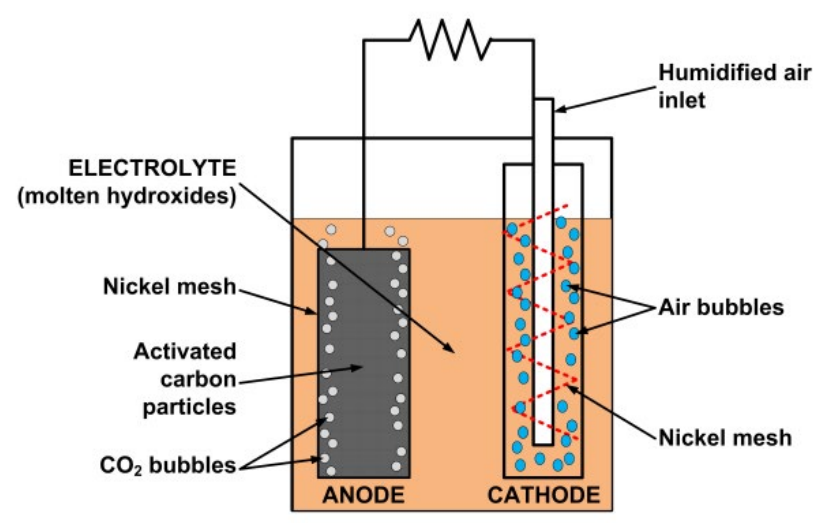

Fig. 8. Schematic drawing of Brown University direct carbon fuel cell Source: figure redrawn based on reference Guo et al. 2013

Rys. 8. Schemat węglowego ogniwa paliwowego skonstruowanego na Uniwersytecie Browna 
Replacements in the anode construction have not resulted in major differences in the performance characteristics of the cell, while the use of the $\mathrm{K} 2$ cathode caused an increase in the power density of the cell by about $50 \%$. In addition, the use of a mixture of $\mathrm{NaOH}$ and $\mathrm{KOH}$ hydroxides allowed the cell to work at lower temperatures than when using $\mathrm{NaOH}$ alone, thanks to which the corrosion rate of materials used in the construction of the device may ultimately be reduced.

\subsubsection{The Częstochowa University of Technology}

The only Polish, and at the same time European, research centre dealing with the theme of direct carbon fuel cells with hydroxide electrolyte is the Department of Energy Engineering (KIE) which is part of the Faculty of Infrastructure and Environment of the Częstochowa University of Technology.

The KIE research team in the course of preliminary experiments, during which three prototypes of direct carbon fuel cells were designed and manufactured (Fig. 9), made the selection and chose the appropriate materials for the individual structural elements of the cell (Kacprzak et al. 2013a).
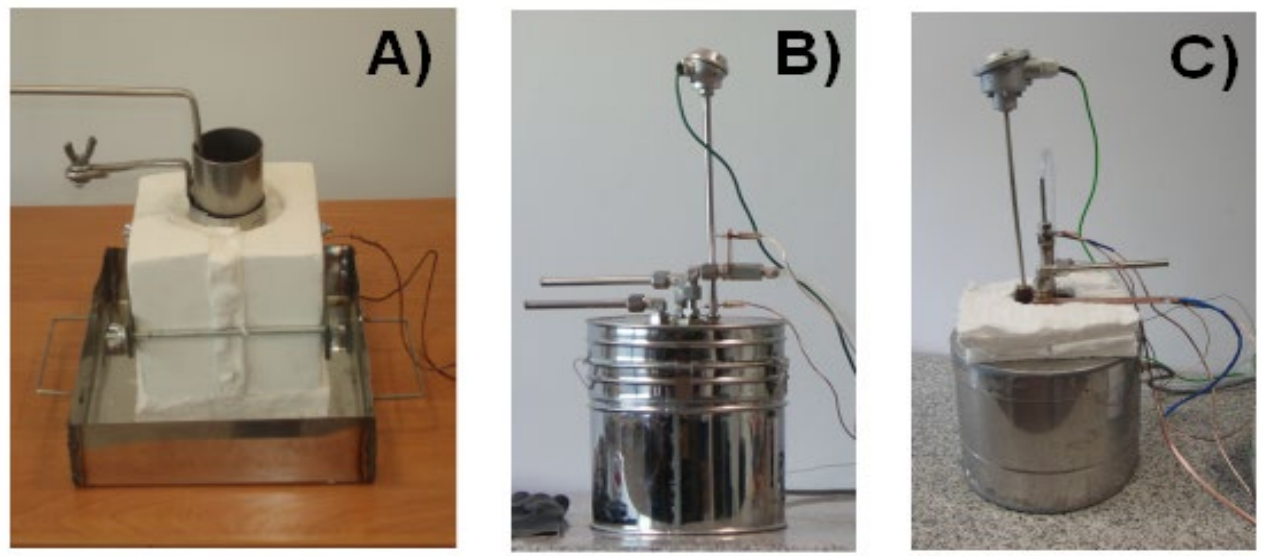

Fig. 9. View of the direct carbon fuel cell prototypes constructed in KIE; A) prototype I - manufactured from the carbon steel, B) prototype II - manufactured from the stainless steel and C) prototype III - manufactured from the nickel and high nickel alloys

Rys. 9. Widok poglądowy modeli węglowych ogniw paliwowych opracowanych w KIE: A) prototyp I - wykonany ze stali węglowej, B) prototyp II - wykonany stali stopowych oraz C) prototyp III wykonany z niklu i stopów wysokoniklowych

Finally, as a result of the carried out preliminary tests and modifications, there was manufactured a nickel model (prototype III, fig. 10), characterized by work stability and repeatability of electrical parameters measurements (unaffected by corrosive processes) under the same conditions at successive time intervals. 

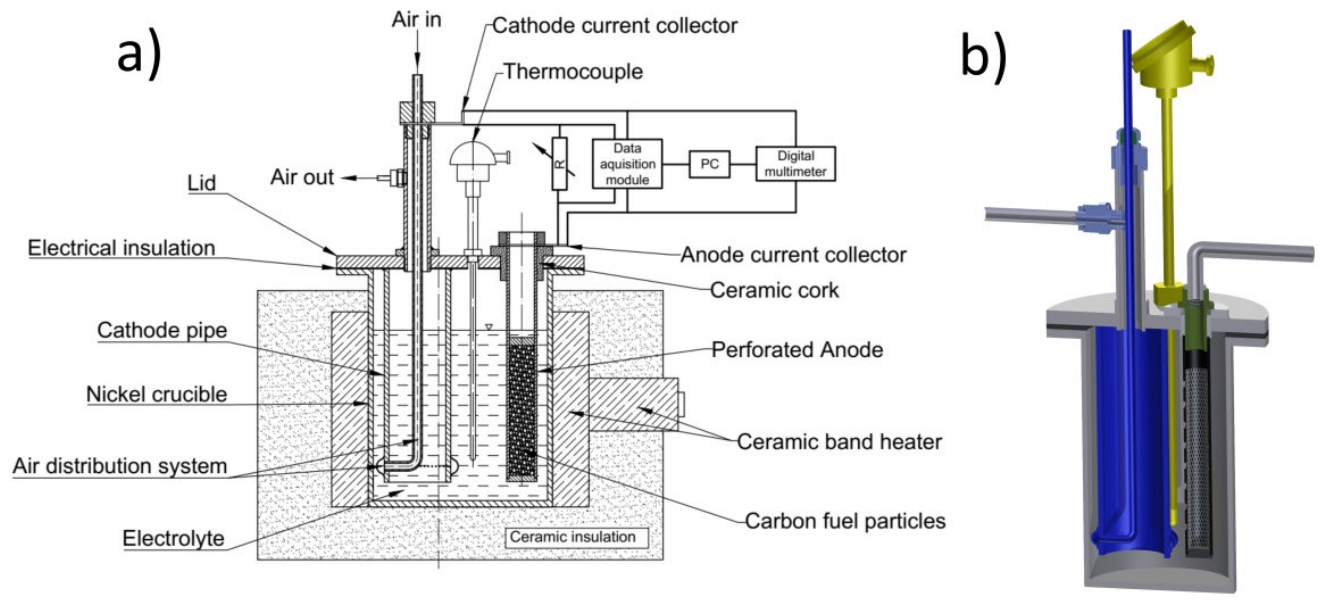

Fig. 10. Construction of a prototype III of direct carbon fuel cell constructed in KIE; a) scheme, b) view

Rys 10. Budowa prototypowego modelu III ogniwa węglowego wykonanego w KIE; a) schemat, b) widok

During the works carried out so far, the research team has focused its efforts, among others, on checking the possibility of using different forms and forms of coal to power the cell. The first successfully completed tests using solid graphite and carbon electrodes encouraged the authors to take the opportunity to use as fuel the crushed hard coal and biochar, being a product of carbonisation of various types of biomass.

The conducted research indicated that the disordered structure of hard coals and biochars resulted in their higher reactivity and susceptibility to electrochemical oxidation in the cell than would be the case in the ordered graphite structure. In addition, there was observed a correlation between the oxygen content in individual fuels and the maximum power density obtained from the cell. The higher the oxygen content in individual fuels (with which correlated was the relative amount of oxygen function groups on the surface of the fuel grains), the higher the maximum power density. In order for this observation to be confirmed, however, there is required further research, already being planned by the authors (Kacprzak et al. 2014).

During subsequent tests, there were determined the influence of individual process parameters (Kacprzak et al. 2013b) as well as the chemical composition of the electrolyte (Kacprzak et al. 2013c) on the electrical parameters obtained from the cell. As part of the work, there was carried out research on the impact of, among others, fuel fragmentation, the amount of air fed to the cathode, electrode surface, chemical composition and electrolyte temperature on such electrical parameters as: current and power density, electromotive force, internal resistance, etc. were carried ouv.

Depending on the type of fuel, values of individual process parameters and of the electrolyte composition, there were obtained power densities in the range from 18 to $42 \mathrm{~mW} \mathrm{~cm}{ }^{-2}$. The highest values were recorded for a cell powered by biochar with a grain size of $0.18-0.25 \mathrm{~mm}$ 
obtained through pyrolysis of apple wood chips, the electrolyte temperature ( $\mathrm{NaOH}-\mathrm{KOH}, 50: 50$ mol\%) of $673 \mathrm{~K}$ and the value of the air stream supplied to the cathode equal to $0,5 \mathrm{dm}_{\mathrm{n}}{ }^{3} \mathrm{~min}^{-1}$.

The estimated energy efficiency of the tested cell was $41 \%$ (in reference to the biochar calorific value), which is a very good and promising result in comparison with other technologies of converting chemical energy of biomass into electrical energy. In turn, the determined electrochemical efficiency was $59 \%$ (at the voltage of $0.65 \mathrm{~V}$ ) and was only $4 \%$ lower than the one theoretically possible to be obtained under the tested conditions (Kacprzak et al. 2016).

\section{Summary}

Direct carbon fuel cells is a technology enabling direct conversion of chemical energy of carbon-based fuels through electrochemical reactions into electrical energy, thanks to which it is possible to achieve high efficiency. The results of research carried out on direct carbon fuel cells with hydroxide electrolyte confirm the possibility of powering them with many types of fuels: from solid graphite and carbon electrodes through crushed hard coal, to the carbonated biomass of various origin (bio-coal). The high-efficiency direct carbon fuel cells presented in the paper are a technology which in the long term,mayoffer a response to the challenges currently facing the energy sector, including to the growing demand for electrical energy, depletion of fossil fuel resources, and increased pollution of the natural environmenv. Among the numerous technical problems stalling further development of the discussed technology, the following should be distinguished:

$\checkmark$ Preparation of coal-based fuel and development of an effective way of its introduction into the cell.

- Selection of materials and development of a structure which ensures adequate availability and durability of the cell.

- Selection of physical (thermodynamic) and chemical conditions allowing to maintainstability of electrolyte and/or to develop an effective and energy-saving method of electrolyte regeneration.

$\downarrow$ Optimization of unit costs and the technological system efficiency with a direct carbon fuel cell.

$\checkmark$ Conducting long-term tests aimed at verifying technical and technological assumptions and confirming the ability of the cell to long-term performance in the conditions of the target industrial energy supply system.

The direct coal fuel cells with an alkaline electrolyte discussed in the papermay be powered not only with hard coal, but also with carbonized plant and waste biomass, which makes them alternative sources of electrical energy using commonly available renewable fuel, characterized by zero $\mathrm{CO}_{2}$ emission. Therefore, they may ultimately be an element of distributed systems 
with power from several $\mathrm{kWe}$ to several hundred $\mathrm{kWe}$ generating electrical energy and heat from biomass, the effective use of which contributes to the implementation of basic principles of the state's energy policy, including mainly:

$\checkmark$ Energy independence.

$\downarrow$ Diversification of primary energy sources and reduction of fossil fuel consumption.

$\checkmark$ Increased efficiency of energy use.

$\downarrow$ Reducing negative impact of the energy sector on the environment and implementing the principles of sustainable development.

\section{References}

ANTAL, M.J. and NiHOUS, G.C. 2008. Thermodynamics of an aqueous-alkaline/carbonate carbon fuel cell. Industrial \& Engineering Chemistry Research vol. 47, iss. 7, pp. 2442-2448.

BASU, P. ed. 2007. Recent Trends in Fuel Science and Technology. Springer and Anamaya, New Delhi, $375 \mathrm{pp}$.

Guo et al. 2013 - GuO, L., CALO, J.M., DiCocCO, E. and BAIN, E.J. 2013. Development of a Low Temperature, Molten Hydroxide Direct Carbon Fuel Cell. Energy \& Fuels vol. 27, iss. 3, pp. 1712-1719.

Guo et al. 2014 - GuO, L., CALO, J. M., KeARnEY, C. and GrimshaW, P. 2014. The anodic reaction zone and performance of different carbonaceous fuels in a batch molten hydroxide direct carbon fuel cell. Applied Energy vol. 129, pp. 32-38.

HACKETT et al. 2007 - HACKETT, G.A., ZONDLO, J.W. and SVENSSON, R. 2007. Evaluation of Carbon Materials for Use in a Direct Carbon Fuel Cell. Journal of Power Sources vol. 168, pp. 111-118.

JACQUES, W.W. 1986. Method of Converting Potential Energy of Carbon Into Electrical Energy, US patent $555511,1896$.

KACPRZAK et al. 2013a - KACPRZAK, A., WŁodARCZYK, R., KobyŁeCKi, R., ŚcisŁowsKa, M. and Bis, I. 2013a. Fuel Cell as Part of Clean Technologies. [In:] Pawłowski A., Dudzińska M.R., Pawłowski L. (ed.) Environmental Engineering IV, CRC Press, Taylor \& Francis Group, London, pp. 443-450.

KACPRZAK et al. 2013b - KACPRZAK, A., KOBYŁECKI, R. and BIS, I. 2013b. The effects of Operating Conditions on the Performance of a Direct Carbon Fuel Cell. Archives of Thermodynamics vol. 34, iss. 4, pp. $187-197$.

KACPRZAK et al. 2013c - KACPRZAK, A., KOBYŁECKI, R. and BIS, I. 2013c.Influence of Temperature and Composition of $\mathrm{NaOH}-\mathrm{KOH}$ and $\mathrm{NaOH}-\mathrm{LiOH}$ Electrolytes on the Performance of a Direct Carbon Fuel Cell. Journal of Power Sources vol. 239, pp. 409-414.

KACPRZAK et al. 2014 - KACPRZAK, A., KOBYŁECKI, R., WŁODARCZYK, R. and BIS, I. 2014. The Effect of Fuel Type on the Performance of a Direct Carbon Fuel Cell with Molten Alkaline Electrolyte. Journal of Power Sources vol. 255, pp. 179-186.

KACPRZAK et al. 2016 - KACPRZAK, A., KOBYŁECKI, R., WŁODARCZYK, R. and BIS, I. 2016. Efficiency of non-optimized direct carbon fuel cell with molten alkaline electrolyte fueled by carbonized biomasp. Journal of Power Sources vol. 321, pp. 233-240.

Lowry, H.H. ed. 1945. Direct Generation of Electrical energy from Coal and Gas (Fuel Cells). Wiley, New York.

Nunoura et al 2007 - Nunoura, V., Dowaki, K., Fushimi, C., Allen, P., MÉszÁros, E. and Antal, M.J., 2007. Performance of a First-Generation, Aqueous-Alkaline Biocarbon Fuel Cell. Industrial \& Engineering Chemistry Research vol. 46, iss. 3, pp. 734-744. 
Patton, E.M. 2003. Sara's Direct Carbon Fuel Cell. Direct Carbon Fuel Cell Workshop, NETL, Pittsburgh (USA).

PATtON, E.M. and ZeCEVIC, P. 2005.Assessment of Direct Carbon Fuel Cells, EPRI report No. 1011496, Palo Alto, California, USA, p. 64.

Report... 2016a. BP Energy Outlook, 2016 Edition: Outlook to 2035, British Petroleum, 2016.

Report... 2016b. International Energy Agency, Energy Policies of IEA Countries - Poland 2016 Review.

Report... 2017. International Energy Agency, World Energy Outlook 2017, Paris, November 2017.

Wolk 2007. Wolk R. H., Lux P., Gelber P., Holcomb F. H., 2007 -Direct Carbon Fuel Cells: Converting

Waste to Electrical energy, Report No. ERDC/CERL TR-07-32, U. P. Army Corps of Engineers.

ZECEVIC et al. 2003 - ZeCEVIC, P., PATTON, E.M. and PARHAMI, P. 2003. Electrochemistry of Direct Carbon Fuel Cell Based on Molten Hydroxide Electrolyte. Direct Carbon Fuel Cell Workshop, Pittsburgh (USA).

Zecevic et al. 2005 - Zecevic, P., Patton, E.M. and Parhami, P. 2005. Direct Electrochemical Power Generation From Carbon in Fuel Cells With Molten Hydroxide Electrolyte. Chemical Engineering Communications vol. 192, iss. 12, pp. 1655-1670.

\section{Analiza obecnego stanu rozwoju technologii węglowych ogniw paliwowych z elektrolitem alkalicznym}

\section{Streszczenie}

Wśród wielu nowoczesnych, wysokosprawnych technologii energetycznych pozwalających na przetwarzanie energii chemicznej węgla w energię elektryczną i ciepło na szczególną uwagę zasługują węglowe ogniwa paliwowe (ang. Direct Carbon Fuel Cells - DCFC). Są to urządzenia, które umożliwiają, jako jedyne spośród wszystkich typów ogniw paliwowych, bezpośrednią konwersję energii chemicznej zawartej w paliwie stałym (węglu) w energię elektryczną. Ponadto charakteryzują się one wysoką sprawnością i niską emisją zanieczyszczeń. W artykule dokonano przeglądu i omówienia dotychczasowych prac badawczo-rozwojowych, prowadzonych zarówno na świecie, jak i w Polsce, nad technologią węglowych ogniw paliwowych z elektrolitem alkalicznym (wodorotlenkowym).

SŁOWA KLUCZOWE: węglowe ogniwo paliwowe, elektrolit alkaliczny, wysokosprawne technologie energetyczne, węgle kopalne 